\title{
Accuracy of the clinical indicators of ineffective health management in celiac people
}

\author{
Acurácia dos indicadores clínicos de controle ineficaz da saúde em celíacos \\ Acuridad de los indicadores clínicos de gestión ineficaz de la salud en celíacos
}

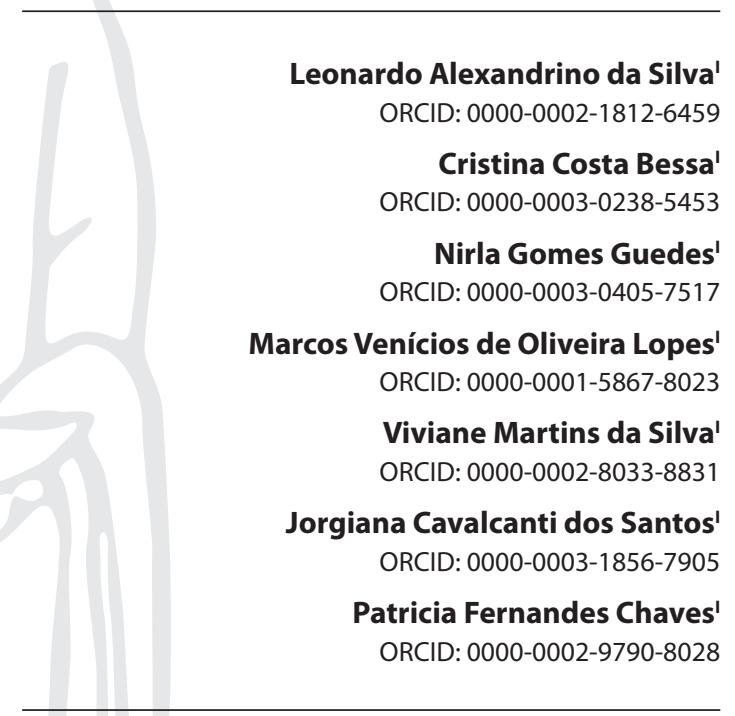

'Universidade Federal do Ceará. Fortaleza, Ceará, Brazil.

How to cite this article: Silva LA, Bessa CC, Guedes NG, Lopes MVO, Silva VM, Santos JC, et al. Accuracy of the clinical indicators of Ineffective health management in celiac people. Rev Bras Enferm. 2020;73(3):e20180739. doi: http://dx.doi.org/10.1590/0034-7167-2018-0739

\section{Corresponding author:}

Nirla Gomes Guedes

E-mail: nirlagomes@hotmail.com

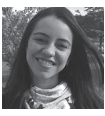

EDITOR IN CHIEF: Antonio José de Almeida Filho ASSOCIATE EDITOR: Hugo Fernandes

Submission: $09-20-2018$

Approval: 05-17-2019

\section{ABSTRACT}

Objective: to analyze the accuracy of clinical indicators of "Ineffective health management" in celiac patients and to verify associations between sociodemographic characteristics and clinical indicators. Method: a cross-sectional study, conducted from May to September 2017, with 83 celiac patients, through an interview. Accuracy measures were defined by latent class model. Results: there was a prevalence of "Ineffective health management" of $55.69 \%$. "Failure to take action to reduce risk factor" and "Failure to include treatment regimen in daily living" better predict this diagnosis. Paid occupation reduces the chance of the presence of "Difficulty with prescribed regimen". Participation in support association reduces the chance of the presence of "Difficulty with prescribed regimen", "Ineffective choices in daily living for meeting health goal" and "Failure to take action to reduce risk factor". Conclusion: accurate clinical indicators identification assists clinical reasoning for diagnostic inference in specific health contexts.

Descriptors: Nursing Diagnosis; Celiac Disease; Chronic Disease; Patient Compliance; Diet, Gluten-Free.

\section{RESUMO}

Objetivo: analisar a acurácia dos indicadores clínicos de "Controle ineficaz da saúde" em celíacos e verificar associações entre características sociodemográficas e indicadores clínicos. Método: estudo transversal, realizado de maio a setembro de 2017, com 83 celíacos, através de entrevista. As medidas de acurácia foram definidas pelo modelo de classe latente. Resultados: houve prevalência de "Controle ineficaz da saúde" de 55,69\%. "Falha em agir para reduzir fatores de risco" e "Falha em incluir o regime de tratamento à vida diária" melhor predizem esse diagnóstico. Ocupação remunerada reduz a chance da presença de "Dificuldade com regime prescrito". Participação em associação de apoio reduz a chance da presença de "Dificuldade com regime prescrito", "Escolhas na vida diária ineficazes para atingir as metas de saúde" e "Falha em agir para reduzir fatores de risco". Conclusão: a identificação de indicadores clínicos acurados auxilia o raciocínio clínico para inferência diagnóstica, em contextos de saúde específicos.

Descritores: Diagnóstico de Enfermagem; Doença Celíaca; Doença Crônica; Cooperação do Paciente; Dieta Livre de Glúten.

\section{RESUMEN}

Objetivo: analizar la exactitud de los indicadores clínicos de "Gestión ineficaz de la salud" en celíacos y verificar asociaciones entre características sociodemográficas e indicadores clínicos. Método: estudio transversal, realizado de mayo a septiembre de 2017, con 83 celíacos, a través de una entrevista. Las medidas de precisión fueron definidas por el modelo de clase latente. Resultados: la prevalencia de "Gestión ineficaz de la salud" fue de $55,69 \%$. El "fracaso al emprender acciones para reducir los factores de riesgo" y "Fracaso al incluir el régimen terapéutico en la vida diaria" mejor dicho este diagnóstico. La ocupación remunerada reduce la posibilidad de la presencia de "Dificultad con el régimen terapéutico prescrito". La participación en la asociación de apoyo reduce la posibilidad de la presencia de "Dificultad con el régimen terapéutico prescrito", "Decisiones ineficaces en la vida diaria para alcanzar los objetivos de salud" y "Fracaso al emprender acciones para reducir los factores de riesgo". Conclusión: la identificación de indicadores clínicos precisos ayuda al raciocinio clínico para inferencia diagnóstica, en contextos de salud específicos.

Descriptores: Diagnóstico de Enfermería; Enfermedad Celíaca; Enfermedad Crónica; Cooperación del Paciente; Dieta Sin Gluten. 


\section{INTRODUCTION}

Celiac disease is an autoimmune enteropathy characterized by gluten intolerance for life. It is considered an underreported public health problem. Every eight individuals with the disease, only one has the medical diagnosis completed ${ }^{(1)}$.

The chronic character is permeated by challenges and conflicts for the therapeutic diet, disease control and health goals achievement. Obstacles to the maintenance of gluten-free diet are multifaceted and have contributed to gluten contamination and, consequently, onset and/or exacerbation of various complications ${ }^{(2-3)}$. On the other hand, effective health control of individuals with chronic disease leads to an increase in quality of life, reduction of health care costs, and absenteeism at work ${ }^{(4)}$.

"Ineffective health management" was approved by NANDA International Classification (NANDA-I) in 1994, and reviewed in 2009-2011, 2018-2020 versions of NANDA-(5). This diagnosis has four clinical indicators: "Difficulty with prescribed regimen";"Ineffective choices in daily living for meeting health goal"; "Failure to take action to reduce risk factor"; and "Failure to include treatment regimen in daily living".

Clinical indicators identification with good prediction for a specific diagnosis increases the reliability of diagnostic inference. Moreover, accuracy measures measurement based on specific definitions and diagnostic tests, subsidizes the diagnostic reasoning and the nurse's ability to satisfactorily classify who has or does not have a specific nursing diagnosis ${ }^{(6-7)}$. Therefore, the accurate inference of "Ineffective health management" will favor a projection of positive health outcomes, considering effective interventions in the context of celiac disease.

The complexity of the factors involved in patient care with chronic disease, difficulties in maintaining a gluten-free diet and the consequences of lack of disease control, reinforce the need to study components of "Ineffective health management". Thus, it would contribute to diagnostic reasoning, improvement of diagnostic inference and, consequently, care plan effectiveness.

In view of this, the following questions arose: what is the prevalence of "Ineffective health management" in celiac individuals? What sociodemographic characteristics of celiac individuals are associated with clinical indicators? Which clinical indicators best predict this nursing diagnosis?

This study will contribute to reduce the existing gap of scientific evidence in clinical practice about "Ineffective health management" in the celiac population, helping to reduce complications due to this phenomenon of nursing, as well as promoting safe and resolute care directed to health control needs.

\section{OBJECTIVE}

This study aims to analyze the accuracy of the clinical indicators of "Ineffective health management" nursing diagnosis in celiac patients and to verify associations between sociodemographic characteristics and clinical indicators.

\section{METHOD}

\section{Ethical aspects}

The Research Ethics Committee of the Universidade Federal do Ceará approved this study. Participants signed the Free and Informed Consent Form.

\section{Design, period and place of study}

A quantitative cross-sectional study carried out in Ceará State from May to September 2017. The research was developed with the members of the Associação dos Celíacos do Brasil-Ceará (ACELBRA-CE - freely translated as Brazil-Ceará Celiac Patients Association) and individuals that were part of the networks and social media (Facebook ${ }^{\circ}$ and WhatsApp ) of ACELBRA, regardless of enrollment in the association. Names and telephones list of those who showed interest in participating in the study was constructed. Then, day, time and place were set for data collection (celiac domicile or in another environment agreed upon between participants and researchers), and the privacy of the interviewees was guaranteed.

\section{Study participants}

The sample consisted of 83 celiac patients, following the recommendation of the minimum value of 20 to 30 subjects for each clinical indicator evaluated ${ }^{(8)}$. Celiac patients of both genders, aged 18 years or older, living in Ceará State, Brazil, with a medical diagnosis of celiac disease, were included. The exclusion criterion was to have some mental/cognitive limitation that compromised the veracity of the data informed during the research, reported by the individual or family or detected at the time of collection. No participant was excluded.

\section{Study protocol}

The data collection took place through an interview with the celiac patient, with an average time of 93 minutes. This was done by a master nurse and three undergraduate students in nursing, scientific initiation fellows. Before starting the data collection, an eight-hour workshop was held to clarify conceptual aspects about celiac disease and "Ineffective health management", as well as training the team to measure each clinical indicator and the variables sociodemographic.

Clinical indicators collection was based on a protocol that included conceptual and operational definitions. This protocol was evaluated by a research group that develops studies on nursing taxonomy, composed of two female doctoral students in nursing, by doctoral students, master and undergraduate students. Five meetings were held, three of an hour and two of an hour and thirty minutes. Protocol was adjusted according to the group discussion and recommendations.

Initially, a pre-test was performed with 12 participants, to evaluate the applicability of the tool. These celiac patients were not excluded from the final sample because the changes made in the tool did not cause significant changes in the responses.

\section{Data analysis}

For the descriptive analysis, the prevalence of sociodemographic variables, central measurement values, occurrence ratios and confidence intervals were calculated. To identify the association between "Ineffective health management" and their respective clinical indicators, the Chi-Square Test or Fisher's Exact Test was used. Odds Ratio and its respective confidence interval were calculated to verify the magnitude of effect between these variables. In the mean difference analysis, the Kolmogorov-Smirnov tests were used to verify the normality of the data. From these data, the Mann-Whitney test was used to verify the mean difference between the groups, with a significance level of 0.05 . 
For the definition of the nursing diagnosis studied, the latent class analysis method was used as reference standard. This technique is used to calculate measures of accuracy when there is no perfect reference standard and is based on the assumption that an unobserved or nursing variable dictates associations between observable variables (clinical indicators and related factors) ${ }^{(9)}$.

A latent class model of random effects was used to calculate the sensitivity, specificity and its $95 \%$ confidence intervals ${ }^{(10)}$. Measurements of sensitivity and diagnostic specificity were used to determine the accuracy measures. Sensitivity was defined by the proportion of celiac patients who manifested "Ineffective health management" in the presence of a certain clinical indicator and the specificity by the proportion of celiac patients without the diagnosis in the absence of certain clinical indicators.

Clinical indicators, which presented values of sensitivity and specificity less than 0.5 or whose $95 \%$ Confidence Interval included this value, were excluded. After exclusion, a new model was adjusted until the Likelihood Ratio Test $\left(\mathrm{G}^{2}\right)$ indicated that it had adequate adjustment ( $p>0.05)$.

Later probabilities, based on the latent class model, were used to identify or not "Ineffective health management", from the presence or absence of each clinical indicator of the adjusted model.

\section{RESULTS}

Of the 83 celiac patients residing in Ceará State, Brazil, half were aged up to 33 , had up to 18 years of schooling, reported income of up to $\$ 670.49$ (American currency) and diagnosis time of celiac disease up to 48 months $(p<0.05)$.

The majority were female (88\%); declared to be white (54.2\%); they had no partner (50.6\%); complied with religion that makes use of gluten in communion ritual (83.1\%); they had paid occupation (75.9\%); were from Fortaleza, Ceará, Brazil (88\%); and participated in a celiac patient support association (62.7\%) (Table 1).

Celiac patients with paid occupation had a $78.8 \%$ reduction in the chance of presenting "Difficulty with prescribed regimen" $(p=0.004)$. Those who participated in a support association had a reduction in the chance of presenting "Difficulty with prescribed regimen","Ineffective choices in daily living for meeting health goal" and "Failure to take action to reduce risk factor", in $66.9 \%(p=0.030)$, $74.3 \%(p=0.257)$ and $81.3 \%(p=0.022)$ respectively (Table 1$)$.

The prevalence of "Ineffective health management" was of $55.69 \%$. The clinical indicators of greater frequency were "Failure to include treatment regimen in daily living" (96.4\%), "Failure to take action to reduce risk factor" (80.7\%) and "Ineffective choices in daily living for meeting health goal" (72.3\%). Celiac individuals who did not present "Difficulty with prescribed regimen" had a $76.8 \%$ reduction in the chance of presenting "Ineffective health management" $(p=0.004 ; O R=0.232)$ (Table 2).

The clinical indicators that stood out were "Failure to take action to reduce risk factor" (Sensitivity: 0.9999), "Failure to include treatment regimen in daily living" (Sensitivity: 0.993), "Ineffective choices in daily living for meeting health goal" (Sensitivity: 0.9843) and "Difficulty with prescribed regimen" (Specificity 0.9420).

Table 1 - Distribution of celiac patients according to the association of sociodemographic variables and "Ineffective health management"

\begin{tabular}{|c|c|c|c|c|c|c|c|c|c|c|c|c|}
\hline \multirow{2}{*}{ Variables } & \multicolumn{2}{|c|}{$\mathrm{Cl} 1$} & \multirow{2}{*}{ Statistics } & \multicolumn{2}{|c|}{$\mathrm{Cl} 2$} & \multirow{2}{*}{ Statistics } & \multicolumn{2}{|c|}{$\mathrm{Cl} 3$} & \multirow{2}{*}{ Statistics } & \multicolumn{2}{|c|}{$\mathrm{Cl} 4$} & \multirow{2}{*}{ Statistics } \\
\hline & A & $\mathbf{P}$ & & A & $\mathbf{P}$ & & A & $\mathbf{P}$ & & & $\mathbf{P}$ & \\
\hline \multicolumn{13}{|l|}{ 1. Gender } \\
\hline Male & 6 & 4 & $p=0.264^{*}$ & 2 & 8 & $\mathrm{p}=0.719^{*}$ & 2 & 8 & $p=1.000^{*}$ & 1 & 9 & $p=0.323^{*}$ \\
\hline Female & 56 & 17 & $\mathrm{OR}=0.455$ & 21 & 52 & $\mathrm{OR}=0.619$ & 14 & 59 & $\mathrm{OR}=1.054$ & 2 & 71 & $\mathrm{OR}=3.944$ \\
\hline Total & 62 & 21 & $\mathrm{Cl}=0.115-1.804$ & 23 & 60 & $\mathrm{Cl}=0.121-3.160$ & 16 & 67 & $\mathrm{Cl}=0.201-5.516$ & 3 & 80 & $\mathrm{Cl}=0.324-47.987$ \\
\hline \multicolumn{13}{|l|}{ 2. Color/Race/Ethnicity } \\
\hline White & 32 & 13 & & 12 & 33 & & 9 & 36 & & 1 & 44 & \\
\hline Black & 2 & 0 & & 1 & 1 & & 1 & 1 & & 0 & 2 & \\
\hline Brown & 20 & 8 & $p=0.278^{* *}$ & 5 & 23 & $p=0.082^{* *}$ & 4 & 24 & $p=0.605^{* *}$ & 2 & 26 & $p=0.654^{* *}$ \\
\hline Yellow & 8 & 0 & & 5 & 3 & & 2 & 6 & & 0 & 8 & \\
\hline Total & 62 & 21 & & 23 & 60 & & 16 & 67 & & 3 & 80 & \\
\hline \multicolumn{13}{|l|}{ 3. Marital Status } \\
\hline With companion & 33 & 9 & $p=0.411^{* *}$ & 10 & 32 & $p=0.422^{* *}$ & 10 & 32 & $p=0.289^{* *}$ & 2 & 40 & $p=1.000^{*}$ \\
\hline Without companion & 29 & 12 & $\mathrm{OR}=1.517$ & 13 & 28 & $\mathrm{OR}=0.673$ & 6 & 35 & $\mathrm{OR}=1.823$ & 1 & 40 & $\mathrm{OR}=2.000$ \\
\hline Total & 62 & 21 & $\mathrm{Cl}=0.559-4.116$ & 23 & 60 & $\mathrm{Cl}=0.256-1.772$ & 16 & 67 & $\mathrm{Cl}=0.595-5.586$ & 3 & 80 & $\mathrm{Cl}=0.174-22.949$ \\
\hline \multicolumn{13}{|l|}{ 4. Religion that makes use of gluten in communion ritual } \\
\hline No & 11 & 3 & $\mathrm{p}=1.000^{*}$ & 3 & 11 & $p=0.748^{*}$ & 3 & 11 & $\mathrm{p}=1.000^{*}$ & 3 & 11 & \\
\hline Yes & 51 & 18 & $\mathrm{OR}=1.294$ & 20 & 49 & $\mathrm{OR}=0.668$ & 13 & 56 & $\mathrm{OR}=1.175$ & 0 & 69 & $p=0.004^{*}$ \\
\hline Total & 62 & 21 & $\mathrm{Cl}=0.324-5.170$ & 23 & 60 & $\mathrm{Cl}=0.168-2.652$ & 16 & 67 & $\mathrm{Cl}=0.286-4.822$ & 3 & 80 & $\mathrm{Cl}=0.598-1.033$ \\
\hline \multicolumn{13}{|l|}{ 5. Paid occupation } \\
\hline No & 10 & 10 & $p=0.004^{* *}$ & 5 & 15 & $p=0.756^{* *}$ & 2 & 18 & $p=0.335^{*}$ & 0 & 20 & \\
\hline Yes & 52 & 11 & $\mathrm{OR}=0.212$ & 18 & 45 & $\mathrm{OR}=0.833$ & 14 & 49 & $\mathrm{OR}=0.389$ & 3 & 60 & $p=1.000^{*}$ \\
\hline Total & 62 & 21 & $\mathrm{Cl}=0.071-0.630$ & 23 & 60 & $\mathrm{Cl}=0.264-2.633$ & 16 & 67 & $\mathrm{Cl}=0.080-1.882$ & 3 & 80 & $\mathrm{Cl}=0.994-1.110$ \\
\hline \multicolumn{13}{|l|}{ 6. Origin } \\
\hline Fortaleza City & 56 & 17 & $p=0.264^{*}$ & 19 & 54 & $p=0.453^{*}$ & 15 & 58 & $p=0.678^{*}$ & 3 & 70 & \\
\hline Metropolitan Region and Ceará State's countryside & 6 & 4 & $\mathrm{OR}=2.196$ & 4 & 6 & $\mathrm{OR}=0.528$ & 1 & 9 & $\mathrm{OR}=2.328$ & 0 & 10 & $\begin{array}{l}p=1.000^{*} \\
\end{array}$ \\
\hline Total & 62 & 21 & $\mathrm{Cl}=0.554-8.700$ & 23 & 60 & $\mathrm{Cl}=0.134-2.075$ & 16 & 67 & $\mathrm{Cl}=0.273-19.834$ & 3 & 80 & $\mathrm{Cl}=0.914-1.006$ \\
\hline \multicolumn{13}{|l|}{ 7. Participation in support associations } \\
\hline No & 19 & 12 & $p=0.030^{* *}$ & 4 & 27 & $p=0.020^{* *}$ & 2 & 29 & $p=0.022^{* *}$ & 1 & 30 & $p=1.000^{*}$ \\
\hline Yes & 43 & 9 & $\mathrm{OR}=0.331$ & 19 & 33 & $\mathrm{OR}=0.257$ & 14 & 38 & $\mathrm{OR}=0.187$ & 2 & 50 & $\mathrm{OR}=0.833$ \\
\hline Total & 62 & 21 & $\mathrm{Cl}=0.120-0.918$ & 23 & 60 & $\mathrm{Cl}=0.078-0.848$ & 16 & 67 & $\mathrm{Cl}=0.0390-0.889$ & 3 & 80 & $\mathrm{Cl}=0.072-9.587$ \\
\hline
\end{tabular}

Note: A: absent; P: present; C11:Difficulty with prescribed diet; C12: Choices in daily life ineffective to achieve health goals; CI3: Failure to act to reduce risk factors; C14: Failure to include the treatmen diet to daily life; OR: Odds Ratio; 95\% Cl: 95\% Confidence Interval; * Fisher's Exact Test; * ${ }^{*}$ Chi-Square Test. 
Table 2 - Distribution according to clinical indicators and "Ineffective health management"

\begin{tabular}{|c|c|c|c|c|}
\hline \multirow{2}{*}{ Clinical indicators } & \multicolumn{2}{|c|}{ IHM ND } & \multirow{2}{*}{ Total } & \multirow{2}{*}{ Statistics } \\
\hline & Absent & Present & & \\
\hline \multicolumn{5}{|c|}{ 1. Difficulty with prescribed regimen } \\
\hline Absent & 17 & 45 & $62(74.7 \%)$ & $p=0.004^{*}$ \\
\hline Present & 13 & 8 & $21(25.3 \%)$ & $\mathrm{OR}=0.232$ \\
\hline Total & 30 & 53 & 83 & $95 \% \mathrm{Cl}: 0.082-0.659$ \\
\hline \multicolumn{5}{|c|}{ 2. Ineffective choices in daily living for meeting health goal } \\
\hline Absent & 8 & 15 & $23(27.7 \%)$ & $p=0.873^{*}$ \\
\hline Present & 22 & 38 & $60(72.3 \%)$ & $\mathrm{OR}=0.921$ \\
\hline Total & 30 & 53 & 83 & $95 \% \mathrm{Cl}: 0.337-2.519$ \\
\hline \multicolumn{5}{|c|}{ 3. Failure to take action to reduce risk factor } \\
\hline Absent & 5 & 11 & $16(19.3 \%)$ & $p=0.650^{*}$ \\
\hline Present & 25 & 42 & $67(80.7 \%)$ & $\mathrm{OR}=0.764$ \\
\hline Total & 30 & 53 & 83 & $95 \% \mathrm{Cl}: 0.238-2.454$ \\
\hline \multicolumn{5}{|c|}{ 4. Failure to include treatment regimen in daily living } \\
\hline Absent & 2 & 1 & $3(3.6 \%)$ & $p=0.295^{* *}$ \\
\hline Present & 28 & 52 & $80(96.4 \%)$ & $\mathrm{OR}=3.714$ \\
\hline Total & 30 & 53 & 83 & $95 \% \mathrm{Cl}: 0.322-42.786$ \\
\hline
\end{tabular}

Note: *Chi-Square Test; OR: Odds Ratio; 95\% Cl: 95\% Confidence Interval; ND: Nursing diagnosis; IHM: Ineffective health management; ** Fisher's Exact Test.

Table 3 - Accuracy measures of the clinical indicators of "Ineffective health management" based on latent class analysis

\begin{tabular}{|c|c|c|c|c|c|c|}
\hline Clinical indicators & Sens. & $95 \% \mathrm{Cl}$ & & Spec. & $95 \% \mathrm{Cl}$ & \\
\hline 1. Difficulty with prescribed regimen & 0.4083 & 0.0366 & 0.9141 & 0.9420 & 0.0028 & 0.9991 \\
\hline 2. Ineffective choices in daily living for meeting health goal & 0.9843 & 0.0572 & 0.9999 & 0.6057 & 0.0290 & 0.9658 \\
\hline 3. Failure to take action to reduce risk factor & 0.9999 & 0.9969 & 1.0000 & 0.4349 & 0.0235 & 0.9280 \\
\hline 4. Failure to include treatment regimen in daily living & 0.9993 & 0.7771 & 1.0000 & 0.0809 & 0.0025 & 0.9230 \\
\hline ND prevalence $=55.69 \%$ & \multicolumn{2}{|c|}{$G^{2}: 3.56$} & \multicolumn{2}{|c|}{ Gl: 6} & \multicolumn{2}{|c|}{$p=0.736$} \\
\hline
\end{tabular}

Note: Sens: sensitivity; Spe: specificity; 95\% Cl: 95\% Confidence Interval; G2: Likelihood Ratio; GI: Degree of Freedom; $p$ : $p$ value.

Although they present high values of accuracy measurements, they have a value lower than $50 \%$, at the lower limit of the confidence interval (Table 3).

For the analysis of the probabilities of "Ineffective health management", based on clinical indicators of the latent class model, 10 sets with different combinations were created. Of these, two indicate the presence of the diagnosis, with probability of presence> 0.5. "Failure to take action to reduce risk factor", "Failure to include treatment regimen in daily living" and "Ineffective choices in daily living for meeting health goal" indicated a probability of $79 \%$ of presence of the diagnosis in question.

\section{DISCUSSION}

The range of clinical manifestations of celiac disease raises a high demand in the multidisciplinary health care teams, in order to elaborate actions that corroborate the implementation of dynamic and efficient care. In this sense, knowing the characteristics of celiac patients contributes to planning and implementation of actions that meet the identified health needs.

Sociodemographic characteristics were common with other studies. Internationally, in populous studies in Colombia, Germany and Saudi Arabia, women prevailed with 88\%, 51.9\% and $52.6 \%$ of the total respectively ${ }^{(11-13)}$. In a study with 10,693 adult celiac patients, there were predominance of those coming from metropolitan and urban regions ${ }^{(14)}$. Among celiac Brazilians, more than $90 \%$ reported having higher education ${ }^{(11,15)}$.
The fact that the majority (83\%) of celiac patients are adherents to the religion that uses gluten in communion ritual may be associated with the country profile. Among Brazilians, $86.8 \%$ are Christians, $64.6 \%$ Catholic and $22.2 \%$ are Evangelical/Protestant ${ }^{(16)}$. In the Holy Supper, a religious ritual of Christians, the devotees are offered two main foods: bread/wafer that represents the body of Jesus Christ, presenting as main ingredient wheat flour; and wine, which symbolizes the blood of Christ. Bread should not be consumed by celiac people. However, the non-consumption of the Host can mean the denial of the presence of Christ and a spiritual birth ${ }^{(17)}$.

The majority (75.9\%) of celiac people have paid occupation and half have income of up to $\$ 670.49$ (American currency), which is higher than the average of Ceará State - Brazil(18) There was a statistically significant association $(p=0.004)$ between paid occupation and "Difficulty with prescribed regimen". In the context of chronic noncommunicable diseases, the higher the patient's income, the easier it is to follow the prescribed diet ${ }^{(19)}$. In this sense, the per capita income of people with celiac disease represents an essential characteristic for the success of their treatment, since products that are certainly free of gluten have a superior value when compared to those that do not contain it ${ }^{(20)}$. Celiac patients, with income of less than $\$ 5,000.00$ (American currency) per year, presented difficulties in following the proposed treatment, especially in the need to attend follow-up visits ${ }^{(15)}$.

Of the celiac patients interviewed, $62.7 \%$ participated in a support association, a result similar to that obtained with 1,835 celiac patients from different regions of the United States ${ }^{(11)}$. Celiac 
patients who participated in a support association had a reduction in the chance of presenting "Difficulty with prescribed regimen", "Ineffective choices in daily living for meeting health goal" and "Failure to take action to reduce risk factor". Celiac members of the support group were more aware of the different nuances of the disease, had a better understanding of celiac disease, were more motivated and sought more information about celiac disease in social media and health services ${ }^{(11)}$. In addition, social support is relevant in celiac disease, since this enteropathy can affect psychological functions and family/social relationships ${ }^{(21)}$.

"Ineffective health management" was present in $55.69 \%$ of celiac patients. The human response "Ineffective self-health management", former label for the diagnosis in question, was present in $86.3 \%$ of the 377 diabetics evaluated in a study ${ }^{(22)}$. Despite the difference in the labeling, it is evident that it is difficult for people with chronic diseases to control the underlying disease and to keep health ${ }^{(23)}$.

"Failure to include treatment regimen in daily living" was the most prevalent and presented high sensitivity. This clinical indicator was understood as the manifestation of signs and/or symptoms suggestive of failure to comply with daily therapy, being investigated through signs and symptoms and/or alterations in the comparative results of reagent antibody tests, digestive endoscopies and duodenal biopsies ${ }^{(24)}$.

In this sense, health professionals need to be aware of the occurrence of clinical manifestations that indicate the breakdown of diet ${ }^{(25)}$. In a study conducted with 321 celiac individuals living in Rome, gluten contamination in laboratory investigations, endoscopic evaluations and imaging tests was detected in 70 participants, although they reported a gluten-free diet for at least 12 months. In addition to laboratory and imaging alterations, they presented pain, abdominal distention, diarrhea, fatigue/lethargy, nausea/vomiting, weight loss/inappetence and infertility/multiple abortions ${ }^{(26)}$. It should be emphasized that extra-intestinal manifestations also need to be investigated and valued in the analysis of therapeutic adherence ${ }^{(27)}$.

In the context of serology for celiac disease, negative results prior to adherence to the gluten-free diet do not necessarily indicate that the occurrence of celiac disease is ruled out. Nonetheless, when the diet is started, positive serology results indicate, among other aspects, a possible contamination/breakdown of $\operatorname{diet}^{(28)}$. In addition, there is good improvement of the intestinal mucosa after two years of the beginning of gluten-free diet, and the total recovery of villi is found after five years ${ }^{(29)}$.

"Failure to take action to reduce risk factor" presented high sensitivity and understood the failure of the celiac individual in the management of risk factors that are related to the lack of control of celiac disease due to cross contamination ${ }^{(30)}$. Crosscontamination can occur in the handling, preparation and consumption of meals in environments and with inputs contaminated by gluten, in different situations and contexts ${ }^{(30)}$. Considering this risk, text messages were effective in the adherence of 61 celiac adolescents to stimulate general purpose utensils and separate/ identified inputs, such as sandwich maker, to mitigate the chance of contamination ${ }^{(31)}$.

In the context of nursing diagnoses, which deal with the standard of regulation and integration of treatment programs, similar results were reported in a diagnostic accuracy study ${ }^{(32)}$. These authors found that "Failure to take action to reduce risk factor" was an indicator of high sensitivity (0.8400) for "Ineffective family therapeutic regimen management".

The challenge of maintaining a gluten-free diet is maximized since there is a possibility that naturally free products such as oats may be contaminated in industrial processes ${ }^{(29)}$. In addition, celiac patients present social difficulties related to treatment for celiac disease, such as eating together with family and friends and how much these aspects impact the quality of life of these patients ${ }^{(33)}$. Therefore, it is up to the nurse to identify the reasons for the difficulties reported by celiac patients, so that they are able to make health decisions based on clinical reasoning and patients' needs.

"Ineffective choices in daily living for meeting health goal" was also prevalent in the sample and sensitive, although it was not statistically significant. This indicator refers to daily behaviors performed by celiac individuals that deviate from the guidelines proposed by health professionals and institutions to avoid contamination by gluten ${ }^{(34)}$.

Inadequate dietary intake of gluten-containing foods, nonlabeling of foodstuffs that are naturally free from gluten, lack of the habit of recognizing reliable establishments as food or glutenfree products, and non-verification of labels and/or composition/ ingredients of various products.

Unintentional contamination during food preparation and processing and ambiguity on food labels are recurrent in the celiac patient ${ }^{(24)}$. Gluten may be present as an excipient or ingredient in the composition of various non-food products ${ }^{(30)}$.

In a prospective study of 160 individuals diagnosed with celiac disease, participants stated that it is not an easy task to find products that are reliably gluten-free, such as pharmaceuticals, makeup and general hygiene ${ }^{(35)}$.

Among the celiac patients, only $21 \%$ presented "Difficulty with prescribed regimen". In the absence of this indicator, there was a reduction in "Ineffective health management". Thus, the difficulty of individuals with chronic diseases, in the following diet, to reach the specific health goals, favors that "Ineffective health management" is common in this population ${ }^{(23)}$.

In the presence of these indicators, quality of life and self-care of the celiac patient may be compromised. The manifestation of these signs/symptoms may indicate the lack of control of the celiac disease and, consequently, the installation of comorbidities and/or complications.

\section{Study limitations}

Some interviews were conducted in public places that may have compromised celiac attention and concentration during data collection. In these cases, an appropriate space was used to conduct the interview and, when necessary, the questions/affirmations were redone and the answers confirmed with celiac patients.

\section{Contributions to Nursing}

Studies on the accuracy of clinical indicators of "Ineffective health management" are scientific evidences that approximate the specific terminologies of the profession in the context of the 
clinic. In addition, these studies are important for understanding the relationship between the set of indicators and the diagnosis. Emphasis is placed on the need for nursing to appropriate this nursing diagnosis that is so significant in the context of chronic diseases, regardless of the level of care or contexts.

\section{CONCLUSION}

83 celiac patients were evaluated, of which $55.69 \%$ presented the nursing diagnosis "Ineffective health management". Celiac patients who have paid occupation have a reduced chance of having "Difficulty with prescribed regimen". Those who participate in a support association are less likely to present "Difficulty with prescribed regimen,"'Ineffective choices in daily living for meeting health goal", and "Failure to take action to reduce risk factor". "Failure to include treatment regimen in daily living" and "Failure to take action to reduce risk factor" are the ones that best predict "Ineffective health management".

Accuracy studies and the identification of good clinical indicators and specific characteristics of a population, which influence the presence of a nursing diagnosis, contribute to an accurate diagnostic inference. Consequently, they collaborate with the development of early actions and strategies to celiac patients' comorbidities and or complications.

\section{REFERENCES}

1. Muniz JG, Sdepanian VL, Fagundes Neto U. Prevalence of genetic susceptibility for celiac disease in blood donors in São Paulo, Brazil. Arq Gastroenterol. 2016;53(4):267-72. doi: 10.1590/S0004-28032016000400011

2. Cosnes J, Nion-Larmurier I. Complications of celiac disease. Pathol Biol (Paris). 2013;61(2):e21-6. doi: 10.1016/j.patbio.2011.03.004

3. Mulder CJ, Wierdsma NJ, Berkenpas M, Jacobs MA, Bouma G. Preventing complications in celiac disease: our experience with managing adult celiac disease. Best Pract Res Clin Gastroenterol. 2015;29(3):459-68. doi: 10.1016/j.bpg.2015.05.006

4. Ministério da Saúde (BR). Portaria no 1.149. Aprova o Protocolo Clínico e Diretrizes Terapêuticas da Doença Celíaca [Internet]. Brasília: Ministério da Saúde; 2015 [cited 2018 Jun 16]. Available from: http://bvsms.saude.gov.br/bvs/saudelegis/sas/2015/prt1149_11_11_2015.html

5. Herdman TH, Kamitsuru S. NANDA international nursing diagnoses: definitions and classification 2015-2017. Oxford: Wiley Blackwell; 2014.

6. Lopes MVO, Silva VM, Araujo TL. Methods for establishing the accuracy of clinical indicators in predicting nursing diagnoses. Int J Nurs Knowl. 2012;23(3):134-9. doi: 10.1111/j.2047-3095.2012.01213.x

7. Zhou X, Obuchowski NA, Mcclish DK. Statistical methods in diagnostic medicine. New York: Wiley Interscience; 2002.

8. Swanson SA, Lindenberg K, Bauer S, Crosby RD. A Monte Carlo investigation of factors influencing latent class analysis: an application to eating disorder research. Int J Eat Disord. 2012;45(5):677-84. doi: 10.1002/eat.20958

9. Collins LM, Lanza ST. Latent class and latent transition analysis with applications in the social, behavioral, and health sciences. New Jersey: John Wiley \& Sons; 2013.

10. Qu Y, Tan M, Kutner MH. Random effects models in latent class analysis for evaluating accuracy of diagnostic tests. Biometrics. 1996;52(3):797-810. doi: 10.2307/2533043

11. Roy A, Pallai M, Lebwohl B, Taylor AK, Green PH. Attitudes toward genetic testing for celiac disease. J Genet Couns. 2016;25(2):270-8. doi: 10.1007/s10897-015-9867-z

12. Kratzer W, Kibele M, Akinli A, Porzner M, Boehm BO, Koenig W, et al. Prevalence of celiac disease in Germany: a prospective follow-up study. World J Gastroenterol. 2013;19(17):2612-20. doi: 10.3748/wjg.v19.i17.2612

13. Aljebreen AM, Almadi MA, Alhammad A, Al Faleh FZ. Seroprevalence of celiac disease among healthy adolescents in Saudi Arabia. World J Gastroenterol. 2013;19(15):2374-8. doi: 10.3748/wjg.v19.i15.2374

14. Pulido O, Zarkadas M, Dubois S, Maclsaac K, Cantin I, La Vieille S, et al. Clinical features and symptom recovery on a gluten-free diet in Canadian adults with celiac disease. Can J Gastroenterol. 2013;27(8):449-53. doi: 10.1155/2013/741740

15. Barbero EM, McNally SL, Donohue MC, Kagnoff MF. Barriers impeding serologic screening for celiac disease in clinically high-prevalence populations. BMC Gastroenterol. 2014;14(1):1-11. doi: 10.1186/1471-230X-14-42

16. Instituto Brasileiro de Geografia e Estatística (IBGE). Pesquisa Nacional de Amostragem de Domicílios [Internet]. Rio de Janeiro, RJ: IBGE; 2012 [cited 2018 Jun 16]. Available from: https://ww2.ibge.gov.br/home/estatistica/populacao/trabalhoerendimento/pnad2011/default.shtm

17. Costa HMP. João Calvino 500 anos: introdução ao pensamento e obra. São Paulo: Cultura Cristã; 2009.

18. Instituto Brasileiro de Geografia e Estatística (IBGE). IBGE divulga o rendimento domiciliar per capita 2016 [Internet]. Rio de Janeiro: IBGE; 2017 [cited 2018 June 16]. Available from: ftp://ftp.ibge.gov.br/Trabalho_e_Rendimento/Pesquisa_Nacional_por_Amostra_de_Domicilios_ continua/Renda_domiciliar_per_capita/Renda_domiciliar_per_capita_2016.pdf

19. Tavares NUL, Luiza VL, Oliveira MA, Costa KS, Mengue SS, Arrais PSD, et al. Free access to medicines for the treatment of chronic diseases in Brazil. Rev Saúde Pública. 2016;50(2):1-10. doi: 10.1590/S1518-8787.2016050006118

20. Villafuerte-Galvez J, Vanga RR, Dennis M, Hansen J, Leffler DA, Kelly CP, et al. Factors governing long-term adherence to a gluten-free diet in adult patients with coeliac disease. Aliment Pharmacol Ther. 2015;42(6):753-60. doi: 10.1111/apt.13319 
21. Rocha S, Gandolfi L, Santos JE. The psychosocial impacts caused by diagnosis and treatment of Coeliac Disease. Rev Esc Enferm USP. 2016;50(1):65-70. doi: 10.1590/S0080-623420160000100009

22. Freitas RW, Araújo MF, Marinho NB, Damasceno MM, Caetano JA, Galvão MT. Factors related to nursing diagnosis, ineffective self-health management, among diabetics. Acta Paul Enferm. 2011;24(3):365-72. doi: 10.1590/S0103-21002011000300010

23. Carneiro CS, Lopes CT, Lopes JL, Santos VB, Bachion MM, Barros ALBL. Conceptual and operational definitions of the defining characteristics and related factors of the diagnosis ineffective health management in people with heart failure. Int J Nurs Knowl. 2017;28(2):76-87. doi: $10.1111 / 2047-3095.12124$

24. Leonard MM, Cureton P, Fasano A. Indications and use of the gluten contamination elimination diet for patients with non-responsive celiac disease. Nutrients. 2017;9(10):1129. doi: 10.3390/nu9101129

25. Boé C, Lozinsky AC, Patrício FR, Andrade JA, Fagundes-Neto U. Celiac disease and constipation: an uncommon atypical clinical manifestation. Rev Paul Pediatr. 2012;30(2):283-7. doi: 10.1590/S0103-05822012000200020

26. Stasi E, Marafini I, Caruso R, Soderino F, Angelucci E, Del Vecchio B, et al. Frequency and cause of persistent symptoms in celiac disease patients on a long-term gluten-free diet. J Clin Gastroenterol. 2016;50(3):239-43. doi: 10.1097/MCG.0000000000000392

27. Burger JP, Brouwer B, IntHout J, Wahab PJ, Tummers M, Drenth JP. Systematic review with meta-analysis: dietary adherence influences normalization of health-related quality of life in coeliac disease. Clin Nutr. 2017;36(2):399-406. doi: 10.1016/j.clnu.2016.04.021

28. Cupertino LH, Oliveira JT, Mucuta PO, Bacelar Júnior AJ, Bacelar LFF. Doença celíaca: uma revisão sistemática. Braz J Surg Clin Res [Internet]. 2016 [cited 2018 Jun 16];16(3):90-6. Available from: https://www.mastereditora.com.br/periodico/20161105_112535.pdf

29. Rubio-Tapia A, Hill ID, Kelly CP, Calderwood AH, Murray JA. ACG clinical guidelines: diagnosis and management of celiac disease. Am J Gastroenterol. 2013;108(5):656-76. doi: 10.1038/ajg.2013.79

30. Andreoli CS, Cortez AP, Sdepanian VL, Morais MB. Avaliação nutricional e consumo alimentar de pacientes com doença celíaca com e sem transgressão alimentar. Rev Nutr;26(3):301-11. doi: 10.1590/S1415-52732013000300005

31. Haas K, Martin A, Park KT. Text message intervention (TEACH) improves quality of life and patient activation in celiac disease: a randomized clinical trial. J Pediatr. 2017;185:62-7.e2. doi: 10.1016/j.jpeds.2017.02.062

32. Mendes LC, Sousa VEC, Lopes MVO. Acurácia das características definidoras do diagnóstico controle familiar ineficaz do regime terapêutico. Acta Paul Enferm. 2011;24(2):219-24. doi: 10.1590/S0103-21002011000200010

33. Araújo HMC, Araújo WMC. Coeliac disease: eating habits and quality of life. Br Food J. 2012;114(9):1297-309. doi: 10.1108/00070701211258835

34. Federação Nacional das Associações de Celíacos do Brasil (FENACELBRA). Guia orientador para celíacos [Internet]. São Paulo: FENACELBRA; 2010 [cited 2018 Jun 16]. Available from: http://www.justica.gov.br/seus-direitos/consumidor/Anexos/guia-orientador-para-celiacos.pdf

35. Wolf RL, Lebwohl B, Lee AR, Zybert P, Reilly NR, Cadenhead J, et al. Hypervigilance to a gluten-free diet and decreased quality of life in teenagers and adults with celiac disease. Dig Dis Sci. 2018;63(6):1438-48. doi: 10.1007/s10620-018-5049-9 